Богдан В.В., Уколов Д.С.

\title{
СРАВНИТЕЛЬНАЯ ХАРАКТЕРИСТИКА ЗАКОНОДАТЕЛЬНОГО РЕГУЛИРОВАНИЯ ИНСТИТУТА ПОЖИЗНЕННОГО СОДЕРЖАНИЯ С ИЖДИВЕНИЕМ В СТРАНАХ-УЧАСТНИЦАХ СОДРУЖЕСТВА НЕЗАВИСИМЫХ ГОСУДАРСТВ
}

Аннотация: В статье исследуется один из актуальнейших вопросов современного гражданского права-пожизненное содержание с иждивением. Анализируется законодательное закрепление данного института в гражданских кодексах государств-участниц СНГ. Основное внимание уделено специифике содержания норм, закрепляюших особенности пожизненного содержания с иждивением, их общиим и отличительным чертам. Особое внимание уделяется рецепции норм Гражданского кодекса Российской Федерации другими странами-участницами СНГ, а также особенностям регулирования рассматриваемых отношений в правопорядках, не упоминающих институт пожизненного содержания с иждивением в национальных Гражданских кодексах. В работе использован сравнительный метод исследования, позволяющий выявить общче и отличительные черты национального законодательства, регулирующего отношения, возникающие из пожизненного содержания с иждивением. Авторы одними их первых поднимают вопросы сравнения положений Гражданских кодексов государств-участнии стран СНГ о пожизненном содержании с иждивением. В результате исследования, авторы приходят к выводу, что единое временное начало развития данного института практически во всех странах СНГ свидетельствует об объективной возможности и перспективности взаимного заимствования отдельных правовых норм, регламентирующих пожизненное содержание с иждивением.

Ключевые слова: Гражданское законодательство, договор ренты, содержание с иждивением, рентные платежи, плательщик ренты, получатель ренты, страны-участнищы СНГ, недвижимое имущество, гарантии получателя рентыл, сравнительное правоведение.

Abstract: This article examines one of the most relevant issues of modern civil law - life estate. The authors analyze the legislation pertaining to this institution within the civil codes of the member-states of the CIS. Emphasis is made on the specificity of the content of norms that govern the aspects of life estate, as well as their general and distinct features. A special attention is given to the reception of the norms of the Civil Code of the Russian Federation by other member-states of the CIS, as well as the special aspects of regulation of these relations within legal systems that do not have the institution of life estate within their national civil codes. The authors are some of the first to raise the issue of comparison of the positions of the civil codes of the CIS member-states on life estate. The authors formulate a conclusion that the concurrent emergence of the norms regulating life estate in virtually all of the CIS countries provides an objective possibility of borrowing separate legal norms that regulate life estate.

Keywords: Civil legislation, Agreement, Life estate, Rent payment, Tenant, Landlord, CIS member-states, Real estate, Landlord guarantees, Comparative legal analysis.

Гражданском кодексе Российской Федерации (далее - ГК РФ) в одном из первых на постсоветском пространстве, впервые был модернизирован подход к вопросу регламентации отношений, возникающих из пожизненного содержания с иждивением. Государства-участники Содружества Независимых государств (далее-СНГ), при разработке национальных гражданских кодексов учли положения российского гражданского законодательства о пожизненном содержании с иждивением, в связи с чем произошла опосредованная рецепция российских норм. Заимствование коснулось не только содержания норм, но и их структуры, а также порядка размещения, что подтверждает содержание Гражданского кодекса Республики Беларусь 1998 г., Гражданского кодекса Республики Кыргызстан 1998 г., Гражданского кодекса Республики Казахстан 1999 г. 
В российском гражданском законодательстве договор пожизненного содержания с иждивением является разновидностью пожизненной ренты и регулируется нормами главы 33 Гражданского кодекса РФ (далее - ГК РФ) «Рента и пожизненное содержание с иждивением».

Согласно п. 1 ст. 583 ГК РФ, по договору ренты одна сторона (получатель ренты) передает другой стороне (плательщику ренты) в собственность имущество, а плательщик ренты обязуется в обмен на полученное имущество периодически выплачивать получателю ренту (далее также - рентный платеж) в виде определенной денежной суммы либо предоставления средств на его содержание в иной форме. Российский закон выделяет три разновидности ренты: постоянная, пожизненная и пожизненное содержание с иждивением.

От вида договора ренты зависят размер ренты и порядок ее выплаты. По общему правилу постоянная рента выплачивается в деньгах в размере, устанавливаемом договором, но в договоре может быть предусмотрено и иное правило: выплата ренты может осуществляться путем предоставления вещей, выполнения работ или оказания услуг, соответствующих по стоимости денежной сумме ренты. Получателями такой ренты могут быть граждане и некоммерческие организации, если это не противоречит закону и соответствует целям их деятельности.

Пожизненная рента определяется в договоре только как денежная сумма, периодически выплачиваемая получателю ренты в течение его жизни. Получателем такой ренты может быть только гражданин.

По общему правилу, по договору пожизненного содержания с иждивением плательщик ренты обязан предоставлять содержание с иждивением, которое может включать в себя обеспечение потребностей в жилище, питании и одежде, а если этого требует состояние здоровья гражданина, также и уход за ним. Договором пожизненного содержания с иждивением может быть также предусмотрена оплата плательщиком ренты ритуальных услуг. И только когда договором пожизненного содержания с иждивением будет предусмотрена возможность замены предоставления содержания с иждивением в натуре выплатой в течение жизни гражданина периодических платежей в деньгах, предоставление содержания меняется на выплату соответствующей денежной суммы ${ }^{1}$.

Следует отметить, что институт пожизненного содержания упоминается в законодательстве всех странучастниц СНГ, кроме Азербайджана и Армении.

${ }^{1}$ Дёмкина А.В. // Новые положения законодательства о размере платежей по договорам ренты. Юрист. 2012. № 8.
Так, Гражданский кодекс Армении 1999 г. регулирует близкий к институту пожизненного содержания институт ренты. При этом в ст. 577 данного кодекса указано, что договором ренты может быть предусмотрена выплата ренты передачей имущества, выполнением работ или предоставлением услуг, соответствующих по стоимости денежной сумме ренты. И хотя в нормах гражданского законодательства Армении не упоминается договор пожизненного содержания, тем не менее, поскольку предоставление услуг может состоять в содержании или ухаживании за получателем ренты, то договор пожизненного содержания с иждивением может возникать на практике и регулироваться нормами договора ренты.

Аналогичное положение содержится в ст. 870 Гражданского кодекса Азербайджана, поэтому так же, как и в Армении, договор пожизненного содержания может регулироваться нормами о договоре ренты.

В Республике Молдова договор отчуждения имущества с условием пожизненного содержания закреплен в отдельной от ренты главе (глава 4 раздела 3 Гражданского кодекса Республики Молдова). Следовательно, пожизненное содержание с иждивением является самостоятельным видом обязательства, а применение к нему норм о договоре пожизненной ренты допускается только в случаях, прямо предусмотренных договором (п. 4 ст. 839 Гражданского кодекса Молдовы).

Гражданское законодательство Республики Таджикистан не содержит положений о договоре ренты. В Гражданском кодексе этого государства закреплен только институт пожизненного содержания с иждивением (глава 32), который, имея свои характерные черты, тем не менее, практически полностью воспроизводит российский институт пожизненного содержания с иждивением. В частности, в ст. 619 Гражданского кодекса Таджикистана содержится положение, согласно которому, стороны могут отказаться от договора пожизненного содержания, если вследствие нарушения договорных обязательств взаимоотношения сторон стали нетерпимыми или по другим существенным причинам чрезвычайно осложненное или невозможное продолжение договора. При этом переданное по договору имущество возвращается отчуждателю, а расходы плательщика ренты (приобретателя) не компенсируются, если договором не установлено другое.

В отличие от норм российского законодательства, указывающим, что предметом договора пожизненного содержания с иждивением может выступать только жилой дом, квартира, земельный участок или иная недвижимость, гражданское законодательство республик 
DOI: $10.7256 / 1811-9018.2015 .8 .10669$

При цитировании этой статьи сноска на доі обязательна

\section{Право и политика 8 (188) • 2015}

Молдовы и Украины предусматривает возможность отчуждения по указанному договору и движимое имущество, «имеющее значительную ценность». Следует отметить, что размер этой «значительной ценности» законодательно не определен, что, по нашему мнению, должно затруднять практическое использование данного положения. Следует согласиться, что «действующий ГК не содержит четких критериев определения «значительной ценности», поэтому в каждом случае, в случае возникновения спора, суд должен назначать независимую экспертизу» ${ }^{21}$.

Субъектный состав договора пожизненного содержания с иждивением во всех странах-участницах СНГ аналогичен: получатель ренты (отчуждатель, выгодоприобретатель, иждивенец) - физическое лицо, независимо от его возраста и состояния здоровья, плательщик ренты (кормилец) - дееспособное физическое лицо, юридические лица.

Гражданское законодательство Республики Узбекистан, выделяющее пожизненное содержание с иждивением в самостоятельную главу 33 , ограничивает круг лиц, имеющих право выступать получателями ренты. Так, ст. 530 Гражданского кодекса Узбекистана предусмотрен специальный субъект - получатель ренты (отчуждатель), которым может выступать только нетрудоспособное по возрасту или по состоянию здоровья лицо, нуждающееся в уходе. Вследствие наличия специального субъекта в качестве получателя ренты, гражданским законодательством данного государства предусмотрено особое основание для расторжения договора отчуждения жилого дома (квартиры) с условием пожизненного содержания по требованию приобретателя: в связи с восстановлением отчуждателем своей трудоспособности (ст. 533).

Гражданским законодательством республик Молдовы, Украины и Узбекистана установлены дополнительные гарантии для получателя ренты в виде запрета плательщику ренты во время действия договора пожизненного содержания с иждивением отчуждать и передавать в залог предмет договора. Так, согласно статье 842 Гражданского кодекса Республики Молдова плательщик ренты (приобретатель) не вправе произвести отчуждение вещи в течение жизни получателя ренты (выгодоприобретателя содержания). В отношении недвижимых вещей данный запрет подле-

\footnotetext{
${ }^{2}$ Комментарий к статье 744: Понятие договора пожизненного содержания (ухода). Электронный ресурс. Доступ к электронному ресурсу: http://ukr-pravo.at.ua/index/ponjatie_dogovora_ pozhiznennogo_soderzhanija_ukhoda/0-2231
}

жит регистрации в реестре недвижимого имущества. Залог или иное обременение вещи разрешается только с согласия выгодоприобретателя содержания. Статья 532 Гражданского кодекса Республики Узбекистан исключает возможность плательщика ренты во время действия договора этот дом (часть дома), квартиру продавать, дарить, закладывать в залог и совершать другие действия, обременяющие право собственности на дом (часть дома), квартиру. На этот дом (часть дома), квартиру не обращается взыскание по долгам приобретателя.

В Гражданском кодексе Украины значительно шире закреплен круг обязанностей приобретателя (плательщика ренты). Так, приобретатель обязан в случае смерти отчуждателя похоронить его, даже если это не было предусмотрено договором пожизненного содержания (ухода). Если же часть имущества отчуждателя перешла к его наследникам, затраты на его погребение должны быть справедливо распределены между ними и приобретателем. В отличие от других стран - участниц СНГ, в Гражданском кодексе Украины подробно закреплены особенности заключения договора пожизненного содержания (ухода) относительно имущества, которое находится в общей совместной собственности. Так, имущество, которое принадлежит совладельцам на праве общей совместной собственности, в частности имущество, которое принадлежит супругам, может быть отчуждено ими на основании договора пожизненного содержания (ухода). В случае смерти одного из совладельцев имущества, которое было отчуждено ими на основании договора пожизненного содержания (ухода), объем обязательства приобретателя соответственно уменьшается. Если отчуждателем является один из совладельцев имущества, которое принадлежит им на праве общей совместной собственности, договор пожизненного содержания (ухода) может быть заключен после определения доли этого совладельца в общем имуществе или определения между совладельцами порядка пользования этим имуществом. Примечательны характерные только для Республики Туркменистан положения Гражданского кодекса, предусматривающие возможность оспаривания договора о пожизненном содержании другими лицами, которые обладают законным правом на получение содержания от кормильца, однако не смогли его получить вследствие заключения кормильцем оспариваемого договора.

Таким образом, следует признать, что гражданское законодательство стран-участниц СНГ при урегулировании института пожизненного содержания с иждивением в целом основаны на нормах российского гражданского права. Наиболее детально институт по- 
жизненного содержания с иждивением урегулирован в законодательстве России и Украины, что объясняется не только заимствованием последней норм российского законодательства, но и большой схожестью отношений, складывающихся в данной сфере. Тем не менее, отдельные положения гражданского законодательства стран СНГ относительно пожизненного содержания с иждивением целесообразно закрепить и в российском гражданском праве. В частности, аналогично гражданскому законодательству республики Узбекистан, представляется необходимым в Гражданском кодексе Российской Федерации закрепить запрет для плательщика пожизненного содержания на обременение имущества, переданного под выплату ренты.

\section{Библиография:}

1. Дёмкина А.В. Новые положения законодательства о размере платежей по договорам ренты. // Юрист. 2012. №8.

2. Крысенкова Н.Б. Рафлюк Е.Е. Обзор II публичных чтений по сравнительному правоведению «Проблемы сравнительного правоведения в условиях интеграции государств» // Журнал зарубежного законодательства и сравнительного правоведения. - 2012. - 6. - С. 167-178.

\section{References (transliterated):}

1. Demkina A.V. Novye polozheniya zakonodatel'stva o razmere platezhei po dogovoram renty. // Yurist. 2012. №8.

2. Krysenkova N.B. Raflyuk E.E. Obzor II publichnykh chtenii po sravnitel'nomu pravovedeniyu "Problemy sravnitel'nogo pravovedeniya v usloviyakh integratsii gosudarstv" // Zhurnal zarubezhnogo zakonodatel'stva i sravnitel'nogo pravovedeniya. - 2012. - 6. - C. 167-178. 